UDC 323.2

Submitted: 04.02.2019

LBC 66.3(2Poc), 1

Accepted: 20.05.2019

\title{
PRACTICES OF INTERACTION OF STATE AND NON-STATE ACTORS IN THE CONTEXT OF REGULATION OF THE MASS COMMUNICATION SYSTEM IN THE RUSSIAN FEDERATION ${ }^{1}$
}

\author{
Sergei I. Morozov \\ Volgograd State University, Volgograd, Russian Federation
}

\begin{abstract}
Introduction. The article represents the author's interpretation of the actor composition of implementing information policy in modern Russia. Special attention is paid to the analysis of the main conditions of interaction between state and non-state structures of the Russian Federation in the process of determining priorities and strategies for ensuring information security in Russia. The problem of this research is actualized by increasing dependence of the mass communication domestic system on modern global geopolitical threats and foreign policy challenges. Russia and Russian society need a set of effective tools and methods to ensure the security and stability of the mass communication system. Methodology and methods. The main methodology of this study is the principles of the communicative approach (N. Wiener, C. Deutsch). Besides, the ideas about the technological core of political communication find their scientific and practical application (S.V. Volodenkov, M. Castells, S.V. Schwarzenberg). The analysis of the combination of public political communication and the processes of administrative-state management is based on the conclusions, which are contained in the articles of G. Lassuela and O.F. Shabrov. The empirical basis of the research is the public opinion polls of "Levada Center". Analysis. The modern world is increasingly differentiated by the degree of information richness: the more the country is informationally open, the faster the production of new ideas, their inclusion in political decisions. The modern process of political communication has shifted to greater interactivity. Information policy, political regulation of the mass communication system becomes the leading sphere of management activities of state and non-state structures. Discussion. The indicative model development of politicalcommunicative interaction of information policy actors in the Russian Federation is hampered by a number of problems. Some of them are associated with established practices of political administration by state institutions of information processes. Other problems come from the unwillingness of civil structures to carry out the functions of public political management in the field of information security. The result is a decline in public confidence in political information and the Russian media. Results. The author proposes the main forms of coordinated interaction of state and non-state actors in the field of information regulation, ensuring the information security of the Russian Federation. The researcher substantiates the idea of the relationship of the mass communication system development with the formation of information and communication competencies of the Russian Federation population.
\end{abstract}

Key words: information, communication, institutional interaction, state, public management, political technologies, system of mass communication.

Citation. Morozov S.I. Practices of Interaction of State and Non-State Actors in the Context of Regulation of the Mass Communication System in the Russian Federation. Vestnik Volgogradskogo gosudarstvennogo universiteta. Seriya 4. Istoriya. Regionovedenie. Mezhdunarodnye otnosheniya [Science Journal of Volgograd State University. History. Area Studies. International Relations], 2020, vol. 25, no. 1, pp. 241-253. (in Russian). DOI:
तิ https://doi.org/10.15688/jvolsu4.2020.1.20 


\title{
ПРАКТИКИ ВЗАИМОДЕЙСТВИЯ \\ ГОСУДАРСТВЕННЫХ И НЕГОСУДАРСТВЕННЫХ АКТОРОВ В КОНТЕКСТЕ РЕГУЛИРОВАНИЯ СИСТЕМЫ МАССОВОЙ КОММУНИКАЦИИ В РОССИЙСКОЙ ФЕДЕРАЦИИ ${ }^{1}$
}

\author{
Сергей Иванович Морозов \\ Волгоградский государственный университет, г. Волгоград, Российская Федерация
}

\begin{abstract}
Аннотация. Введение. В статье представлена авторская интерпретация акторного состава реализации информационной политики в современной России. Особое внимание уделяется анализу основных условий взаимодействия государственных и негосударственных структур РФ в процессе определения приоритетов и стратегии обеспечения информационной безопасности России. Проблематика данного исследования актуализируется возрастающей зависимостью отечественной системы массовой коммуникации от современных глобальных геополитических угроз и внешнеполитических вызовов. Российскому государству и обществу необходим набор эффективных инструментов и методов обеспечения безопасности и стабильности функционирования системы массовой коммуникации. Методология и методы. Основной методологией данного исследования выступают принципы коммуникативного подхода (Н. Винер, К. Дойч). Кроме того, нашли свое научно-практическое применение идеи о технологическом ядре политической коммуникации (С.В. Володенков, М. Кастельс, С.В. Шварценберг). Анализ соединения публичной политической коммуникации и процессов административно-государственного управления базируется на выводах, содержащихся в работах Г. Лассуэла и О.Ф. Шаброва. Эмпирической основой исследования выступают опросы общественного мнения населения «Левада-центра». Анализ. Современный мир все более дифференцируется по степени информационной насыщенности: чем больше страна информационно открыта, тем быстрее происходит производство новых идей, их включение в политические решения. Современный процесс политической коммуникации сместился к большей интерактивности. Информационная политика, политическое регулирование системы массовой коммуникации становятся ведущими сферами управленческой деятельности государственных и негосударственных структур. Дискуссия. Развитию индикативной модели политико-коммуникативного взаимодействия акторов информационной политики в РФ препятствует ряд проблем. Часть из них связана с сложившимися практиками политического администрирования государственными институтами информационных процессов. Другие проблемы исходят из неготовности гражданских структур осуществлять функции публичного политического управления в сфере обеспечения информационной безопасности. Следствием этого является снижение доверия населения к политической информации и российским СМИ. Результаты. Предложены основные формы координированного взаимодействия государственных и негосударственных акторов в сфере информационного регулирования, обеспечения информационной безопасности РФ. Обоснована идея взаимосвязи развития системы массовой коммуникации с формированием информационно-коммуникативных компетенций населения РФ.
\end{abstract}

Ключевые слова: информация, коммуникация, институциональное взаимодействие, государство, публичное управление, политические технологии, система массовой коммуникации.

Цитирование. Морозов С. И. Практики взаимодействия государственных и негосударственных акторов в контексте регулирования системы массовой коммуникации в Российской Федерации // Вестник Волгоградского государственного университета. Серия 4, История. Регионоведение. Международные отношения. 2020. - T. 25, № 1. - C. 241-253. -DOI: https://doi.org/10.15688/jvolsu4.2020.1.20

Введение. Ускоряющийся процесс изменения информационно-коммуникационных технологий актуализирует исследование с различных научно-теоретических подходов к решению вопросов взаимодействия государственной власти и общества по поводу фор- мирования, хранения и передачи информации. В связи с этим важно уточнить содержание понятия «система массовой коммуникации» В контексте обеспечения взаимодействия государственной власти и общества, обусловленного мировыми изменениями в сфере комму- 
никации и информатизации. Поскольку система массовой коммуникации создает возможности как для социального диалога и развития других сфер жизни общества, так и для дестабилизации и разрушения, поэтому целесообразно определить способы государственного регулирования в данной области.

Процесс регулирования системы массовой коммуникации предполагает наличие действующих акторов, его осуществляющих. В данном исследовании «акторность» интерпретируется прежде всего как проявление активной политической субъектности в процессе принятия решений на основании собственных политических интересов, ценностей, идей, а также на основании прикладного анализа политической ситуации. В силу этого политические акторы в качестве «лидеров» социальнополитического процесса могут формировать институциональные «правила игры», привлекать и использовать властно-управленческие ресурсы, обеспечивая устойчивое воспроизводство и развитие политической системы общества.

В связи с демократизацией общества, помимо государственных структур, появляются новые акторы, без участия которых невозможно осуществление современной информационной политики. В связи с этим важно интерпретировать акторный состав участников реализации информационной политики, условия и цели их взаимодействия. В современном мире необходимо нахождение баланса интересов личности, общества и государства в различных сферах (включая политическую и информационную), который определится характером взаимодействия политических и общественных институтов и лиц. Поэтому представляет научный интерес поиск моделей такого взаимодействия с выявлением их альтернатив.

Россия активно включена в мировые современные международные процессы, и ее стратегия информационной политики должна соответствовать актуальным вызовам внутри страны и на мировой арене. Для того чтобы понять, как эффективно реализовывать информационную политику и регулировать сферу массовой коммуникации, важно определить условия для развития информационной сферы и общественно-политических отноше- ний, охарактеризовать результаты взаимодействия участников данных отношений на сегодняшний день.

Связующим интересом государственных и общественных структур является обеспечение безопасности как одной из базовых ценностей сохранения и развития форм социальной жизнедеятельности. В данной связи научную значимость представляет также анализ мероприятий по организации координированного взаимодействия государственных и негосударственных акторов в России в условиях перехода к информационному обществу как адаптации к глобальным изменениям и совершенствования основных общественных сфер, противостояния новым и традиционным угрозам современных мировых процессов.

Методология и методы исследования. Основной методологией исследования выступают идеи коммуникативного подхода, позволяющие интерпретировать взаимодействие государственной власти и общества как процесс обмена и передачи информации соответственно информационной парадигме современного социума. Осмысление содержания современной системы массовой коммуникации основывается как на теоретических идеях Н. Винера, К. Дойча, так и на представлениях о технологическом ядре политической коммуникации С.В. Володенкова, С.В. Шварценберга, М. Кастельса. Не менее значимы теоретические идеи О.Ф. Шаброва о соединении политической и управленческой сфер во взаимодействии власти и общества, а также понимание структурных компонентов модели массовой коммуникации Г. Лассуэла. Анализ эмпирической информации основывается на количественных методах сбора и обработки данных аналитического центра Юрия Левады «Левада-центр» (Всероссийский опрос общественного мнения населения в 52 субъектах РФ).

Анализ. В политологических исследованиях концепт коммуникации активно используется уже более полувека, позволяя раскрыть и охарактеризовать множество противоречий и скрытых сторон политической жизни, описать содержательные аспекты политического взаимодействия и властных отношений, их изменение и развитие в сложной сфере политики. Кроме того, он имеет ключевое отношение к наступившей постиндустриальной 


\section{ВЛАСТЬ И ОБЩЕСТВО}

эпохе и ее историческому смыслу, помогает в осмыслении перехода к новому типу политического сообщества и организации власти.

Новые формы общественной жизни были порождены «технизированной» и «информатизированной» средой. На рубеже XXI в. общество находится в среде постоянных технологических достижений и основывается на умении все большего числа людей обрабатывать информацию. Общественные изменения были замечены в работах множества зарубежных и отечественных исследователей, различно характеризовавших «новое общество». К ним относятся работы А. Турена о «программируемом» обществе, Р.Е. Лейна об «обществе, основанном на знаниях» ("the knowledgeable society”), Р. Дарендорфа о «посткапиталистическом» обществе, но наиболее популярными стали характеристики современного общества как «постиндустриального» или «информационного». Как отмечает А.В. Манойло, в таком обществе «главными составляющими труда становятся знания и информация, легкий и свободный доступ к информации по всему миру» [12, с. 8]. Таким образом, современный мир все более дифференцируется не по уровню экономического развития, а по степени информационной насыщенности: чем больше страна информационно открыта, тем быстрее люди «обрабатывают информацию», «принимают решения» и «действуют»; быстрее происходит производство новых идей, их имплементация в политические решения.

Необходимо заметить, что значение имеет не любая информация, и даже не «политическая информация», а та, которая имеет смысловую значимость, то есть «политически значимая». Вместе с тем, предполагая наличие обратной связи, можно говорить о политическом диалоге, который в неявном виде содержит управленческие моменты. Согласно О.Ф. Шаброву, следует говорить о существовании области пересечения двух областей - теории управления и политической науки, которая называется политическим управлением, а наука - управленческой политологией $[6$, с. 85]. То есть это есть не что иное, как пересечение «политической коммуникации» с «управлением».

Но на протяжении всего XX в. сформировался и получил развитие технически опос- редованный процесс хранения, распространения, обмена и восприятия информации численно большими и рассредоточенными аудиториями, иной тип коммуникации - массовый. В работах Г. Лассуэлла массовая коммуникация интерпретируется как целеориентированный процесс направленного воздействия на аудиторию посредством соответствующего информационного контента. Подобное воздействие производится средствами массовой информации на аудиторию, не имеющую горизонтальных связей и представляющую массу изолированных друг от друга людей. Люди потребляют пропагандистскую информацию по вертикальным каналам односторонней коммуникации. В данном случае пропагандист инициатор политической коммуникации, активный субъект коммуникационного управления, который использует значимые символы для осуществления воздействия в формате пропаганды при помощи средств массовой коммуникации. Следовательно, средства коммуникации - это материальный компонент процесса коммуникации, выражающий собой способ производства и распространения идей, ценностей в обществе (печать, радио, телевидение, компьютерные сети).

Важной представляется идея М. Кастельса об основном векторе политической коммуникации: «осуществление власти есть процесс генерирования и трансляции информации и культурных кодов, которые и обеспечивают содержательные основы власти, базирующейся на коммуникационных технологиях» [11]. В связи с этим массовое поведение является результатом внедрения в массовое сознание политических ценностей тех, кто контролирует каналы массовой коммуникации.

Кроме того, современный процесс информирования сместился к большей интерактивности. Значительный вклад в это внесла глобальная сеть Интернет, которая изменила функционирование официальных государственных и негосударственных структур, принципы функционирования Интернета экстраполировались на традиционные СМИ. Под влиянием этих процессов органы государственной власти обзаводятся собственными сайтами для расширенной передачи сведений для граждан в онлайн-режиме, возникают интернет-при- 
емные президентов и лидеров политических партий; статусные лица государства используют Интернет для общения с политическими институтами и гражданами. Этой коммуникативной модели следуют вертикально интегрированные «низовые» политические структуры, использующие пространство блогосферы и иные сетевые структуры.

Содержание информационных потоков, инициируемых СМИ, так или иначе контролируется и регулируется высшими исполнительными структурами государства. Однако официальные представители властных структур в силу институциональных «правил игры» постоянно ставят под сомнение такие выводы, ссылаясь на наличие и многообразие независимых СМИ, государственный контроль за которыми невозможен. Однако если допустить, что публичная политическая коммуникация задается и формируется несколькими национальными (планетарными) СМИ, то ситуация окажется несколько иной. Таким образом, подобное создавшееся положение в медиасфере с установлением политико-административного контроля над ведущими источниками массовой информации формирует и направляет информационные потоки, ограничивая гражданское волеизъявление. Но у государственной власти имеется обоснование такой позиции, а точнее - необходимость обеспечения порядка, стабильности и безопасности общества.

Новый тип политической коммуникации оказывает влияние на реализацию власти внутри государства, взаимодействие государства и общества, требуя от государственных институтов власти выработку иных подходов к информационно-коммуникационной деятельности, иного понимания места и роли индивида и общества в сложившихся условиях. При этом понятие «массы» приобретает новое звучание за счет «структуризации сетевых сообществ» [16, с. 225] в форматах, рассчитанных как для единоличной, так и многопользовательской коммуникации, что связано также с использованием высокотехнологичных гаджетов и наличием в сообществах виртуальных лидеров общественного мнения.

Система массовой политической коммуникации расширяется, увеличивая технологическую и информационную базу, вместе с тем растут ее участники, возникают новые формы передачи информации и самой коммуникации. Но для того, чтобы организовать конструктивный общественно-политический диалог в данной системе, необходимо ее регулирование, введение (норм, правил, целей, связей), связывающее данный вид деятельности с политико-управленческими процессами, как способом «исправления ошибок». Как известно, политика возникает там, где есть проблемы, в решении которых возникают альтернативные пути и различные социальные силы или само государство. Таким образом, как отмечает С.В. Володенков, политическое регулирование становится «самостоятельным и ведущим видом управленческой деятельности, который легитимирует все остальные уровни управления и самоуправление в целом, приобретающее политический характер» [2, с. 7].

В отношении взаимодействия власть СМИ - общество проблема регулирования является дискуссионной, поскольку не достаточно четко возможно очертить границы публичного и частного, определить принципы «фильтрации» информационного контента. В связи с этим регулирование системы массовой коммуникации должно осуществляется как на уровне государственных (муниципальных) структур, так и институциональными структурами гражданского общества. А.А. Морозов выделяет три группы методов регулирования СМИ и системы массовой коммуникации: правовые, экономические и политические [13]. Основным регулятором взаимоотношений между властью, обществом и акторами масс-медиа в правовом государстве могут выступать только нормативно-правовые акты. Среди экономических методов регулирования достаточно широко используется предоставление для средств массовой информации таможенных и/ или фискальных льгот, с целью создания благоприятных условий для распространения общественно- и политически важной информации, в частности содействующей образованию, воспитанию, культурному досугу граждан. В ряде зарубежных стран законодательством также предусмотрено выделение бюджетных средств и субсидий для финансирования целевых расходов некоторых общественно-значимых СМИ (например, ФРГ, Франция, Австрия, США). К политическим методам регу- 


\section{ВЛАСТЬ И ОБЩЕСТВО}

лирования относится поддержка государственных СМИ, кадровая политика. На данный момент основной формой реализации медиаменеджмента в политическом процессе является учредительство. Для множества региональных (местных) СМИ в качестве соучредителей выступают органы государственной и муниципальной власти, что не может не сказываться определенным образом на содержании и подаче информационного контента: телевидение и пресса обладают «мощным манипулятивным потенциалом» [2], позволяя эффективно транслировать целевой аудитории значимые смыслы, ценности и символы.

Тем не менее активно формирующаяся глобальная система массовой коммуникации, развитие информационно-коммуникативных технологий все более трансформируют политико-коммуникативное пространство. Политическая коммуникация все более детерминируется виртуальной политической реальностью, сетью Интернет, системами и сервисами Web 2.0. Мультимедийность, экстерриториальность и интерактивность интернет-ресурсов способствуют разрушению традиционных символов и политико-культурных пространств, внедрению в массовое сознание новых политических мифов, ценностей и стереотипов, обусловливая тем самым уровень стабильности/дестабилизации тех или иных политико-территориальных сообществ.

От содержания, объема и полноты информационного обеспечения населения зависит уровень легитимности государственнополитических институтов, степень электоральной активности, понимание необходимости соблюдения законов и иных государственных предписаний. Чтобы избежать дестабилизирующей и дезинтегрирующей информации, необходима соответствующая информационная политика: регулярный сбор информации о состоянии политической системы, привлечение СМИ к отражению потребностей социума и поддержанию баланса общественных настроений, обеспечение устойчивости политико-коммуникативных каналов и средств. Определенным маркером качества информационной политики, устойчивости и транспарентности коммуникации общественных и властных институтов является инфор- мационная безопасность страны. С точки зрения важности поддержания упорядоченности политической системы и качества политического процесса особо значимой угрозой информационной безопасности общества становится внедрение дезинформации или информации негативного характера. Поэтому постоянно актуализируется необходимость существования специализированных государственных и негосударственных «фильтрующих» структур, обеспечивающих нейтрализацию негативной информации, пресекающих применение манипулятивных технологий и кибератак.

Акторами информационной политики выступают различные социально-политические группы общества, государственные учреждения и организации в зависимости от господствующего типа политической культуры населения, комбинации авторитарных и демократических тенденций при реализации политического режима в отношении системы власть - СМИ - общество. Цели и содержание государственной информационной политики формируют институциональные структуры государственной власти координирующего и управляющего характера; центры ситуационного анализа при различных правительственных ведомствах; технические центры, обеспечивающие защиту информации и выработку образцов информационного контакта для вхождения в мировое информационно-политическое пространство. Информационно-коммуникационное взаимодействие государства и гражданского общества формируется параллельно, в рамках создания и развития открытой площадки идей, где властные институты в качестве контрагентов обмениваются целями и результатами деятельности со множеством общественно-экспертных советов, медиахолдингов аналитических структур и PR-служб исследовательской и научной направленности.

Кроме того, О.Ф. Волочаева указывает на важность неинституциональных акторов политической коммуникации в информационном обществе - социальные движения [3, c. 99]. Они не в полной мере могут быть включены в институциональные каналы публичной политики, контролируемые структурами власти или ограниченной группой политэкспертов (политтехнологов). В общественные движения вливаются политические аутсайдеры и 
маргинальные политические группы, отстраненные по каким-либо причинам от участия в процедуре принятия политических решений.

Тем не менее ключевой (системообразующей) частью информационной политики является государственная информационная политика, которая представляет собой «деятельность органов государственной власти с целью регулирования информационной сферы общества, включающую в себя информационные и телекоммуникационные системы или СМИ, отношения и процесс производства, создания, хранения, обработки и передачи информации в различных аспектах - официально-новостном, развлекательном, научном, образовательном и деловом» [14].

Существует три модели взаимодействия элементов системы массовой коммуникации: «императивная», «социо-ориентированная» и «индикативная». Первая основывается на обеспечении жесткого мониторинга, контроля за государственными институтами всех элементов инфраструктуры массовой коммуникации. В рамках второй модели «аудитория» - совокупность независимых потребителей информации осуществляет обратную связь с органами власти; система массовой коммуникации ориентируется на аудиторию, готовую платить за контент и потреблять рекламируемую продукцию.

Наиболее валидна «индикативная» модель. Она ориентирована на обеспечение возможности открытого доступа граждан к созданию и распространению информационных сообщений по каналам массовой коммуникации; возможность потребления информации коррелирует в целом с коммуникативными правами населения. Однако широкому распространению данной модели, по мнению Е.С. Устинович, могут препятствовать следующие проблемы коммуникационного взаимодействия основных акторов информационной политики [17]:

- постоянные попытки осуществления манипуляций со стороны властных структур в общении с населением; некорректная или дозированная информация; обилие чрезмерно позитивной информации о достижениях и успехах в работе органов власти;

- субъективное восприятие представителями власти «вынужденности» работы с обращениями граждан; слабая коммуникативная некомпетентность государственных служащих; предпочтение монологичных, односторонне направленных форм политической коммуникации;

- устойчивое недоверие населения органам власти, особенно регионального и местного уровней; высокий уровень политической пассивности граждан: нежелание и неготовность самостоятельно собирать и критически обрабатывать политическую информацию.

Дискуссия. Следует отметить, что в современном политико-коммуникативном пространстве России, несмотря на признание значения информационного обеспечения для выработки и осуществления общенациональной государственной политики, нет единства в понимании содержания и инструментов информационной политики. Как отмечают Ю.Е. Бурова и Д.Л. Стровский, федеральные программы, ориентированные на развитие инновационных IT-технологий, сосредоточивали внимание на организационно-технологических аспектах данного вопроса, а идея улучшения взаимоотношений с обществом оставалась далеко не на первом месте [1, с. 25]. Более того, следует согласиться с В.М. Казиевым, что на данный момент в России информация есть властный ресурс, используемый в политической сфере. И этот ресурс огромен, дорог и сложен. Он включает в себя различные базы данных, электронные информационные массивы, архивные фонды и т. д. Но по уровню использования этих ресурсов Россия отстает от развитых стран мира [10]. Финансируются административно значимые информационные системы, системы таможенных и налоговых служб, государственных органов, выборов, органов правопорядка. По словам А.И. Завьялова, Россия «не имеет необходимых средств и производственных возможностей для самостоятельного развития национальной информационно-телекоммуникационной инфраструктуры, поэтому вынуждена привлекать капитал и технологию из более развитых стран» [8, с. 141].

Подобная ситуация сложилась в отношении технологий информатизации и связи, которые включают в себя совокупность экономических, технических и программных средств для улучшения реализации деятельности структур социально-политической сфе- 


\section{ВЛАСТЬ И ОБЩЕСТВО}

ры, будь то сфера производства или система государственного управления. Отечественный рынок технологий информатизации и связи ориентирован на зарубежные технические средства, что приводит к снижению производства отечественных разработок в данной области.

Тем не менее, несмотря на определенные проблемы в правовом урегулировании СМИ, отечественные масс-медиа - это не только инструмент государственного воздействия на массовое сознание и на общественное мнение. Постепенно укрепляющиеся независимые СМИ, в том числе в сети Интернет, становятся все более значимыми институтами отечественной публичной политики, определяя характер и направленность деятельности органов государственной власти. Характерным примером тому могут служить регулярно появляющиеся результаты независимых журналистских расследований о фактах коррупции и о злоупотреблениях служебным положением представителей федеральных, региональных и муниципальных органов власти.

Президент РФ В.В. Путин по случаю Дня прав человека в декабре 2016 г. указал на необходимость информационной открытости государства перед формируемым гражданским обществом. Основополагающая необходимость формирования в РФ открытого информационного пространства с условием обеспечения целостности и единства государства является стратегическим приоритетом реализации федеральной программы «Информационное общество (2011-2020 годы)» [4]. Программа содержит перечень проблем, препятствующих осуществлению эффективной государственной информационной политики: зависимость от зарубежных информационных технологий, разрозненность государственных информационных ресурсов и дублирование данных, увеличение количества компьютерных преступлений и материального ущерба от их последствий. Более того, утвержденная в декабре 2016 г. Доктрина информационной безопасности Российской Федерации содержит основные направления обеспечения информационной безопасности:

- противодействие использованию информационных технологий для совершения правонарушений, пропаганды противоправных действий особой общественной опасности;
- пресечение ущерба от деятельности, осуществляемой с использованием технических средств и информационных технологий;

- повышение защищенности критической информационной инфраструктуры и устойчивости ее функционирования, развитие механизмов обнаружения и предупреждения информационных угроз;

- обеспечение безопасности информации, передаваемой и обрабатываемой в информационных системах с целью устойчивого взаимодействия органов государственной власти;

- обеспечение защиты информации ограниченного доступа и распространения, в том числе за счет повышения защищенности соответствующих информационных технологий;

- повышение эффективности информационного обеспечения реализации государственной политики Российской Федерации [7].

В Доктрине также указаны основные угрозы информационной безопасности: «угрозы информационному обеспечению государственной политики; развитию отечественной индустрии информации, включая индустрию средств информатизации, телекоммуникации и связи, а также обеспечению эффективного использования отечественных информационных ресурсов; безопасности информационных и телекоммуникационных средств» [7] на территории России.

Однако рейтинг доверия к органам государственной власти (за исключением Президента РФ), которые непосредственно призваны решать данные приоритетные проблемы, у россиян достаточно низкий. Как показывают исследования Левада-Центра, к началу 2019 г. с утверждением, что «государство выполняет сейчас свои обязанности перед гражданами» согласились лишь 20 \% граждан России; треть опрошенных затруднились с ответом. Примерно треть респондентов уверены в том, что «государство дает так мало, что мы ему ничем не обязаны»; примерно половина опрошенных, то есть каждый второй гражданин РФ высказывает мнение, что от государства «можно требовать и большего» или уверенность в необходимости «заставить государство служить нашим интересам» [5]. Кроме того, как демонстрируют результаты замера общественного мнения в конце 2018 г., правительственным институтам, призванным 
определять стратегию и непосредственно реализовывать государственную информационную политику, доверяют лишь 27 \% граждан РФ (для сравнения, традиционно менее популярным в оценках граждан региональным органам власти - $29 \%$ ).

В процессе реализации информационной политики государственные структуры взаимодействуют со СМИ, конструируя информационную повестку дня. СМИ освещают выступления руководителей органов государственной власти, интервью политиков и лидеров политических партий, публичные дискуссии в экспертном сообществе. В.А. Шакирова отмечает две основные цели, руководствуясь которыми властные структуры являются активаторами политической коммуникации: во-первых, создание востребованного образа политического института и его поддержание, во-вторых, коррекция созданного образа [18, с. 77]. При этом, с учетом того, что современное общество массовой культуры не терпит однообразия, акторам государственной информационной политики приходится «удивлять» и даже «забавлять» население. Многочисленные телевизионные «шоу» общественно-политической направленности на российских федеральных телеканалах имеют своей основной целью скорее «развлечение» аудитории, нежели удовлетворение потребности населения в достоверной и всесторонней политической информации. На наш взгляд, это обусловлено медиакратической способностью государства обеспечивать политическую стабильность. Характер и содержание информационных потоков, создаваемых и направляемых федеральными СМИ, так или иначе контролируется исполнительными структурами государства. Но официальные представители властных структур, по мнению А.И. Соловьева, как правило, опровергают такие выводы, ссылаясь на то, что в стране зарегистрировано более 25 тысяч СМИ, за которыми невозможен государственный контроль. Политический контроль и «самоцензура» журналистов сохраняют разнообразие позиции в сфере сообщений о культуре, но не в сфере политически значимых вопросов. В условиях политически и административно ограниченного информационного пространства лишь частично идет речь о расширении гласности и прозрачности действий власти [16, с. 225].
На данном фоне обращают на себя внимание рейтинги доверия населения российским СМИ: печать, радио и телевидение вполне заслуживают доверия 31 \% граждан; не вполне заслуживают и совсем не заслуживают - суммарно $62 \%$ населения РФ [9]. Если принимать во внимание тот факт, что абсолютное большинство россиян предпочитают телевизионный контент и чаще всего получают новости о ситуации в стране из телевизора, вывод достаточно пессимистичен. Население не склонно доверять сформировавшейся в России системе массовой коммуникации, не заинтересовано в поддержании политикокоммуникативного взаимодействия с государственными и негосударственными властными институтами. Из этого следует, что современные условия диктуют проработку новых аспектов национальных интересов Российской Федерации в сфере реализации информационной политики.

Необходимо принять тот факт, что информационная политика распространяется на все общество в целом, интересы его институтов и отдельных граждан, интересы органов государственной власти различных ветвей и уровней, влияет на внутреннюю и внешнюю политику государства, государственная информационная политика начинается с разработки концепции и организации контроля над ее реализацией. Это находится в непосредственном ведении Президента РФ в соответствии с его функциями и обязанностями, возложенными на него Конституцией РФ. Сегодня только государственные институты могут обеспечить защиту общества и его граждан от масштабной внешней и внутренней информационной агрессии. Но в настоящее время государственная информационная политика продолжает находиться в состоянии поиска новых способов управляемости, эффективных в условиях политической публичности и информационной открытости современного общества.

Кроме того, одной из приоритетных задач реализации современной информационной политики в РФ становится минимизация рисков и угроз, связанных с внешнеполитическими (глобальными) противоречиями и геополитическими вызовами, с которыми вынужденно столкнулось российское государство и общество в последние годы. Безусловно, вопро- 
сы обеспечения информационной безопасности приоритетно относятся к компетенции специализированных органов государственной власти. Однако большая результативность в решении данных задач должна быть связана с развитием координированного политико-коммуникативного взаимодействия административных и общественных структур в информационной сфере. В условиях все возрастающей публичности сферы российской политики, постепенных, хоть и противоречивых практик демократизации общественных отношений, только подобного рода координированное взаимодействие позволит сгладить наиболее острые противоречия и конфликтные ситуации в сфере объектов и предметов информационного регулирования.

Свидетельством начала формирования общественно-политической системы реализации информационной политики и поддержания информационной безопасности в РФ является постепенное вовлечение общественных организаций и гражданских объединений в разработку актуальной «повестки дня». Например, Научный совет при Совете Безопасности РФ, в состав которого входят руководители научно-образовательных учреждений, академики РАН, известные представители экспертноаналитических структур и исследовательских центров, обеспечивает научную основу для анализа особо важных проблем обеспечения информационной безопасности, занимается независимой экспертизой вопросов защиты информации. Факт участия институтов гражданского общества России в процессе обеспечения информационной безопасности отмечается многими исследователями, однако лишь как начинающий проявляться.

Тем не менее А.Н. Сапожникова отмечает, что «гражданское общество в России должно принимать участие в разработке альтернативных моделей и элементов отечественной стратегии по борьбе с кибертерроризмом, электронным мошенничеством, компьютерными атаками и прочими угрозами информационной безопасности государства и граждан» [15, с. 5-6]. И общественные институты демонстрируют готовность принимать участие в выработке и реализации общенационального вектора информационной политики. Российское политологическое сообщество регулярно проводит тематические конгрессы, международные и всероссийские конференции, межрегиональные круглые столы и экспертные семинары, привлекая к активному участию представителей органов власти и управления, средства массовой коммуникации, политтехнологов, с целью обсуждения актуальных вопросов и выработки рекомендаций по регулированию общенационального информационного пространства. Комплекс данных мероприятий имеет своей не менее важной задачей создание общероссийской публичной дискуссионной площадки обсуждения содержания и реализации информационной политики для мобилизации широких слоев населения к поддержке действий государственных и негосударственных институтов в области распространения и использования информации, обеспечения информационной безопасности.

Результаты. Современная государственная информационная политика связывается с процессом развития массовой коммуникации и глобализации информационного пространства в рамках прикладных моделей многостороннего взаимодействия специальных акторов. Основными акторами, осуществляющими информационную политику, являются: органы государственной и муниципальной власти (как узкоспециализированные, так и широкого профиля); институты гражданского общества (медиахолдинги, СМИ и др.); индивидуальные политические акторы, лидеры общественного мнения и т. д. Целью взаимодействия является обеспечение информационной безопасности (внешней, внутренней, корпоративной или частной).

Комбинация акторов и характер функциональных полномочий определяют тип политико-коммуникативной модели взаимодействия институтов власти и общества. В рамках доминирующей модели политической коммуникации в России явно проявляется недостаточно координированное взаимодействие отечественных государственных и негосударственных акторов; наблюдается отсутствие четких, институционально закрепленных «правил игры» в сфере информационного регулирования, обеспечения информационной безопасности. Свидетельством тому является достаточно негативное отношение многих представителей экспертного сообщества и 
политической медиасферы к качеству и проработанности принятого в Государственной Думе РФ законопроекта о контроле за публикациями в сети Интернет, в электронных и печатных СМИ и недостоверной информации. К подобного рода противоречивым вопросам об объекте и предмете государственной информационной политики следует отнести и дискуссии о создании и государственном регулировании отечественного сегмента сети Интернет. На наш взгляд, способность СМИ выполнять основную свою функцию - предоставление объективной, полной и достоверной информации должна в большей мере связываться со способностями системы массовой коммуникации к результативному взаимодействию государственных и негосударственных структур в процессе определения «правил игры» и реализации информационной политики в РФ.

К приоритетным формам развития отечественной системы массовой коммуникации следует отнести: общенациональные дискуссионные площадки с привлечением представителей федеральных и региональных властных структур, СМИ, экспертно-аналитического сообщества; развитие отечественного интернет-сегмента; развитие системы социальных контрактов с независимыми массмедиа общественно-политической направленности; реализация программ формирования информационно-коммуникативных компетенций для различных групп населения; развитие системы гражданской ответственности за защиту персональной или общественно значимой информации.

\section{ПРИМЕЧАНИЕ}

${ }^{1}$ Исследование выполнено при финансовой поддержке РФФИ и Администрации Волгоградской области в рамках научного проекта № 19-411340006 р_а «Социально-политическое проектирование публичного пространства и системы массовой коммуникации в регионах РФ (на примере Волгоградской области)».

The reported study was funded by RFBR and Volgograd Region Administration in the framework of research project no. 19-411-340006 p_a "Socio-Political Design of Public Space and Mass Communication System in the Regions of the Russian Federation (The Example of the Volgograd Region)".

\section{СПИСОК ЛИТЕРАТУРЫ}

1. Бурова, Ю. Е. Информационная политика и ее формирование в современных российских условиях / Ю. Е. Бурова, Д. Л. Стровский // Известия Уральского федерального университета. Серия 1, Проблемы образования, науки и культуры. - 2014. № 1 (123). - С. 21-34.

2. Володенков, С. В. Интернет-коммуникации в глобальном пространстве современного политического управления / С. В. Володенков. - Электрон. текстовые дан. - Режим доступа: http://partnersdnld. litres.ru/static/trials/21/53/56/21535692.a4.pdf(дата обращения: 28.01.2019). - Загл. с экрана.

3. Волочаева, О. Ф. Политические процессы в современном информационном обществе: новые акторы и векторы развития : дис. ... д-ра полит. наук : 23.00.02 / Волочаева Оксана Федоровна. - Пятигорск, 2015. - 300 с.

4. Государственная программа Российской Федерации «Информационное общество (20112020 годы)». - Электрон. текстовые дан. - Режим доступа: http://www.rg.ru/2010/11/16/infobschestvosite-dok.html (дата обращения: 28.01.2019). - Загл. с экрана.

5. Граждане и государство: исследования аналитического центра Юрия Левады «Левадацентр». - Электрон. текстовые дан. - Режим доступа: https://www.levada.ru/2019/01/22/grazhdane-igosudarstvo-3 (дата обращения: 28.01.2019). - Загл. с экрана.

6. Грачев, М. Н. Политическая коммуникация: понятие, сущность / М. Н. Грачев // Политическая коммуникативистика: теория, методология, практика / под ред. Л. Н. Тимофеевой. - М. : Российская ассоциация политической науки (РАПН) : Российская политическая энциклопедия (РОССПЭН), 2012. - C. 77-90.

7. Доктрина информационной безопасности Российской Федерации. - Электрон. текстовые дан. - Режим доступа: https://rg.ru/2016/12/06/ doktrina-infobezobasnost-site-dok.html (дата обращения: 28.01.2019). - Загл. с экрана.

8. Завьялов, А. И. Основные тенденции государственного управления в информационной сфеpe / А. И. Завьялов // KANT. - 2013. - № 3 (9). C. $141-145$.

9. Институциональное доверие: исследования аналитического центра Юрия Левады «Левадацентр». - Электрон. текстовые дан. - Режим доступа: https://www.levada.ru/2018/10/04/institutsionalnoe-doverie-4 (дата обращения: 28.01.2019). - Загл. с экрана.

10. Казиев, В. М. Основы правовой информатики и информатизации правовых систем / В. М. Казиев. - Электрон. текстовые дан. - Режим доступа: 
http://www.irbis.vegu.ru/repos/10870/Html/86.htm (дата обращения: 28.01.2019). - Загл. с экрана.

11. Кастельс, М. Галактика Интернет: размышления об Интернете, бизнесе и обществе. - Электрон. текстовые дан. - Режим доступа: http://bwbooks.net/ index.php?id1 $=4 \&$ category $=$ comp-lit\&author=kastelm\&book=2004 (дата обращения: 28.01.2019). - Загл. с экрана.

12. Манойло, А. В. Государственная информационная политика в особых условиях / А. В. Манойло. - М. : МИФИ, 2003. - 388 с.

13. Морозов, А. А. Методы регулирования деятельности СМИ сквозь призму мирового опыта / А. А. Морозов. - Электрон. текстовые дан. - Режим доступа: http://www.kisi.kz/ru/categories/ politicheskaya-modernizaciya/posts/metodyregulirovaniya-deyatel-nosti-smi-skvoz-prizmu-mi (дата обращения: 28.01.2019). - Загл. с экрана.

14. Нисневич, Ю. А. Информационная политика России: проблемы и перспективы / Ю. А. Нисневич. - Электрон. текстовые дан. - Режим доступа: http://text.tr200.biz/referat ostaljnye_referaty/?referat= 736165\&page=1 (дата обращения: 28.01.2019). - Загл. с экрана.

15. Сапожникова, А. С. Взаимодействие государства и общества в политике информационной безопасности РФ / А. С. Сапожникова // Государственное управление. Электронный вестник. - 2009. - Вып. 19 (июнь). - Электрон. текстовые дан. - Режим доступа: http://e-journal.spa.msu.ru/uploads/vestnik/2009/ vipusk_19._ijun_2009_g._sapozhnikova.pdf. - Загл. c экрана.

16. Соловьев, А. И. Медиаспособности государства как фактор развития российского общества: проблемы и практики / А. И. Соловьев // Политическая коммуникативистика: теория, методология, практика / под ред. Л. Н. Тимофеевой. М. : Российская ассоциация политической науки (РАПН) : Российская политическая энциклопедия (РОССПЭН), 2012. - С. 222-233.

17. Устинович, Е. С. Проблемы взаимодействия субъектов коммуникативно-информационного пространства современной России / Е. С. Устинович // Современные научные исследования и инновации. - 2011. - № 6. - Электрон. текстовые дан. Режим доступа: http://web.snauka.ru/issues/2011/10/ 4021 (дата обращения: 28.01.2019). - Загл. с экрана.

18. Шакирова, В. Информационная политика это реализация «властной идеи» / В. Шакирова // Обозреватель-Observer. - 2014. - № 8. - С. 77-83.

\section{REFERENCES}

1. Burova Yu.E., Strovskiy D.L. Informatsionnaya politika i ee formirovanie $\mathrm{v}$ sovremennykh rossiyskikh usloviyakh [Information Policy and Its Formation in Modern Russian Conditions]. Izvestiya Uralskogo federalnogo universiteta. Seriya 1, Problemy obrazovaniya, nauki i kultury [Izvestia Ural Federal University Journal. Series 1. Issues In Education, Science And Culture], 2014, no. 1 (123), pp. 21-34.

2. Volodenkov S.V. Internet-kommunikatsii v globalnom prostranstve sovremennogo politicheskogo upravleniya [Internet Communications in the Global Space of Modern Political Governance]. URL: http:// partnersdnld. litres.ru/static/trials/21/53/56/21535692.a 4.pdf(accessed 28 January 2019).

3. Volochaeva O.F. Politicheskie protsessy $v$ sovremennom informatsionnom obshchestve: novye aktory $i$ vektory razvitiya: dis. ... d-ra polit. nauk [Political Processes in the Modern Information Society: New Actors and Development Vectors. Dr. polit. sci. diss.]. Pyatigorsk, 2015. 300 p.

4. Gosudarstvennaya programma Rossiyskoy Federatsii "Informatsionnoe obshchestvo (20112020 gody)» [State Program of the Russian Federation "Information Society (2011-2020)"]. URL: http://www. rg.ru/2010/11/16/infobschestvo-site-dok.html (accessed 28 January 2019).

5. Grazhdane i gosudarstvo: issledovaniya analiticheskogo tsentra Yuriya Levady «Levadatsentr» [Citizens and the State: Research of the Analytical Center of Yuri Levada "Levada Center"]. URL: https://www.levada.ru/2019/01/22/grazhdane-igosudarstvo-3 (accessed 28 January 2019).

6. Grachev M.N. Politicheskaya kommunikatsiya: ponyatie, sushchnost [Political Communication: Concept, Essence]. Timofeeva L.N., ed. Politicheskaya kommunikativistika: teoriya, metodologiya, praktika [Political Communication Studies: Theory, Methodology, and Practice]. Moscow, Rossiyskaya assotsiatsiya politicheskoy nauki (RAPN), Rossiyskaya politicheskaya entsiklopediya (ROSSPEN), 2012, pp. 77-90.

7. Doktrina informatsionnoy bezopasnosti Rossiyskoy Federatsii [Doctrine of Information Security of the Russian Federation]. URL: https://rg. $\mathrm{ru} / 2016 / 12 / 06 /$ doktrina-infobezobasnost-site-dok.html (accessed 28 January 2019).

8. Zavyalov A.I. Osnovnye tendentsii gosudarstvennogo upravleniya $\mathrm{v}$ informatsionnoy sfere [The Main Trends of Public Administration in the Information Sphere]. KANT, 2013, no. 3 (9), pp. 141-145.

9. Institutsionalnoe doverie: issledovaniya analiticheskogo tsentra Yuriya Levady «Levadatsentr» [Institutional Trust: Research of the Analytical Center of Yuri Levada "Levada Center"]. URL: https: //www.levada.ru/2018/10/04/institutsionalnoe-doverie4 (accessed 28 January 2019).

10. Kaziev V.M. Osnovy pravovoy informatiki $i$ informatizatsii pravovykh sistem [Fundamentals of 
Legal Informatics and Informatization of Legal Systems]. URL: http://www.irbis.vegu.ru/repos/10870/ $\mathrm{Html} / 86 . \mathrm{htm}$ (accessed 28 January 2019).

11. Kastels M. Galaktika Internet: razmyshleniya ob Internete, biznese i obshchestve [Galaxy Internet: Reflections on the Internet, Business and Society]. URL: http://bwbooks.net/index.php?id $1=4 \&$ category $=$ comp-lit\&author $=$ kastel-m\&book $=2004$ (accessed 28 January 2019).

12. Manoylo A.V. Gosudarstvennaya informatsionnaya politika $v$ osobykh usloviyakh [State Information Policy in Special Conditions]. Moscow, MIFI, 2003.388 p.

13. Morozov A.A. Metody regulirovaniya deyatelnosti SMI skvoz prizmu mirovogo opyta [Methods of Regulating the Activities of the Media Through the Prism of World Experience]. URL: http:// www.kisi.kz/ru/categories/politicheskayamodernizaciya/posts/metody-regulirovaniya-deyatelnosti-smi-skvoz-prizmu-mi (accessed 28 January 2019).

14. Nisnevich Yu.A. Informatsionnaya politika Rossii: problemy i perspektivy [Information Policy of Russia: Problems and Prospects]. URL: http://text. tr200.biz/referat_ostaljnye_referaty/?referat $=736$ 165\&page $=1$ (accessed 28 January 2019).

15. Sapozhnikova A.S. Vzaimodeystvie gosudarstva i obshchestva $v$ politike informatsionnoy bezopasnosti RF [Interaction of the State and Society in the Information Security Policy of the Russian
Federation]. Gosudarstvennoe upravlenie. Elektronnyy vestnik [E-Journal. Public Administration], 2009, June, iss. 19. URL: http://e-journal.spa.msu.ru/uploads/ vestnik/2009/vipusk_-19._ijun_2009_g._/ sapozhnikova.pdf.

16. Solovyev A.I. Mediasposobnosti gosudarstva kak faktor razvitiya rossiyskogo obshchestva: problemy i praktiki [Media Capabilities of the State as a Factor in the Development of Russian Society: Problems and Practices]. Timofeeva L.N., ed. Politicheskaya kommunikativistika: teoriya, metodologiya, praktika [Political Communication Studies: Theory, Methodology, and Practice]. Moscow, Rossiyskaya assotsiatsiya politicheskoy nauki (RAPN), Rossiyskaya politicheskaya entsiklopediya (ROSSPEN), 2012, pp. 222-233.

17. Ustinovich E.S. Problemy vzaimodeystviya subyektov kommunikativno-informatsionnogo prostranstva sovremennoy Rossii [Problems of Interaction of Subjects of the Communicative Information Space of Modern Russia]. Sovremennye nauchnye issledovaniya i innovatsii [Modern Scientific Researches and Innovations], 2011, no. 6. URL: http://web.snauka.ru/issues/2011/10/4021 (accessed 28 January 2019).

18. Shakirova V. Informatsionnaya politika - eto realizatsiya «vlastnoy idei» [Information Policy Is the Realization of the "Power Idea"]. Obozrevatel [Observer], 2014, no. 8, pp. 77-83.

\section{Information About the Author}

Sergei I. Morozov, Candidate of Sciences (Politics), Associate Professor, Department of International Relations, Political Science and Area Studies, Volgograd State University, Prosp. Universitetsky, 100, 400062 Volgograd, Russian Federation, morozovsi@volsu.ru, https://orcid.org/0000-0002-4802-9203

\section{Информация об авторе}

Сергей Иванович Морозов, кандидат политических наук, доцент кафедры международных отношений, политологии и регионоведения, Волгоградский государственный университет, просп. Университетский, 100, 400062 г. Волгоград, Российская Федерация, morozovsi@volsu.ru, https://orcid.org/0000-0002-4802-9203 